\title{
PENGGUNAAN MIKROOGRANISME LOKAL (MoL) DAUN SIRIH MERAH (Piper porphyrophyllum N.E.Br.) DAN BIJI SRIKAYA (Annona squamosa L.) UNTUK MENGENDALIKAN INVASI KEPIK HITAM (Paraeucosmetus pallicornis Dallas) PADA TANAMAN PADI
}

\author{
Inrianti $^{1)}$ dan Sepling Paling ${ }^{2)}$ \\ 1) Staf Pengajar Prodi Agroteknologi STIPER Petra Baliem Wamena, Jayawijaya, Papua \\ 2) Staf Pengajar Prodi Pendidikan Matematika STKIP Kristen Wamena, Jayawijaya, Papua \\ E-mail: ${ }^{1)}$ inrianticute@yahoo.com
}

\begin{abstract}
ABSTRAK
Kepik Hitam merupakan salah satu hama yang menginvasi bulir padi sehingga menyebabkan produksi padi menjadi rendah dan kualitas beras yang dihasilkan juga rendah. Kualitas beras yang rendah akan mempengaruhi tingkat kesejahteraan petani yang ada di beberapa daerah di Indonesia dan pada akhirnya akan berpengaruh terhadap tingkat perekonomian bangsa dan negara. Untuk itu, tujuan penelitian ini dilakukan adalah untuk mengetahui daya bunuh Mikroorganisme Lokal $(\mathrm{MoL})$ daun sirih merah dan larutan $\mathrm{MoL}$ biji srikaya dalam mengendalikan serangan hama kepik hitam yang menyerang malai padi. Penelitian dilaksanakan melalui 3 tahap yaitu pembuatan MoL, perbanyakan serangga uji, dan uji efektifitas MoL pada kepik hitam. Kemudian data yang diperoleh dianalisis dengan menggunakan analisis Variance (ANAVA) melalui uji $\mathrm{F}$ dan dilanjutkan dengan uji LSD/BNT. Hasil penelitian yang diperoleh bahwa penggunaan larutan MoL daun sirih merah 3\% melalui kontak makanan kepik hitam dengan cara perendaman malai padi selama 2 hari menunjukkan tingkat mortalitas kepik hitam yang lebih tinggi yaitu 92,5\% dibandingkan dengan perlakuan melalui kontak integumen dengan cara penyemprotan yaitu sebesar sebesar $82,5 \%$. Selanjutnya perlu dilakukan penelitian lanjutan dalam mengidentifikasi metabolit sekunder mikroba yang terdapat dalam larutan MoL daun Sirih merah dan larutan MoL ekstrak biji Srikaya yang berperan untuk mematikan kepik hitam.
\end{abstract}

Kata Kunci: Kepik Hitam, Sirih Merah, Srikaya, Mikroorganisme Lokal (MoL), Tanaman Padi

\section{PENDAHULUAN}

Tanaman padi (Oryza sativa) merupakan salah satu komoditas yang paling penting bagi penyediaan pangan utama di Indonesia. Hal ini dikarenakan padi merupakan bahan pokok utama yang dikonsumsi oleh masyarakat Indonesia pada umumnya. Oleh karena itu, produksi padi seyogyanya ditingkatkan dari tahun ke tahun sejalan dengan pertambahan jumlah penduduk di Indonesia. Peningkatan produksi padi akan mempengaruhi tingkat kesejahteraan masyarakat. Selain itu, peningkatan produksi padi atau beras bertujuan untuk meminimalisir impor beras dari 
negara lain. Hal ini juga berdampak pada meningkatnya devisa negara.

Salah satu kendala utama dalam meningkatkan hasil pertanian tanaman padi adalah adanya serangan hama kepik hitam (Paraeucosmetus pallicornis Dallas). Serangan kepik hitam pada tanaman padi sangat merugikan petani padi karena beras yang dihasilkan memiliki kualitas yang rendah. Penurunan kualitas beras disebabkan invasi kepik hitam dengan cara memasukkan stiletnya ke dalam bulir padi dan menghisap cairan yang ada dalam bulir padi sehingga bulir padi menjadi coklat dan beras menjadi coklat kehitaman. Selain itu, pada saat digiling gabah (bulir padi) sangat rapuh (patahpatah) dan terasa pahit jika dikonsumsi (Baskoro, 2009).

Rauf dan Lanya (2009) menemukan adanya serangan hama baru kepik penghisap bulir padi di Desa Matani dan Popontolen, Kabupaten Minahasa Selatan dan mendapati adanya serangan kepik hitam pada tanaman padi fase generatif, rerumputan di galengan dan tepi Sungai Kwarter. Jumlah populasi kepik hitam yang menyerang pertanaman tersebut sangat tinggi dengan tingkat serangan $50 \%$ pada hamparan sekitar 5 ha. Jumlah populasi yang METODE PENELITIAN

Penelitian ini merupakan penelitian eksperimental yang dilakukan di Laboratorium dan ditemukan sekitar 2 - 20 ekor per rumpun (Rauf dan Lanya, 2009).

Sebelumnya telah dilaporkan oleh Rauf dan Lanya (2008) bahwa kepik hitam telah menyebar di beberapa wilayah seperti Provinsi Gorontalo, Sulawesi Selatan, dan Kalimantan Timur. Laporan BBPOPT bekerjasama dengan IP3OPT (2011) menyatakan adanya invasi hama kepik hitam di lahan pertanian padi sawah di Kabupaten Wajo. Bahkan saat penelitian ini dilakukan, telah ditemukan hama kepik hitam di persawahan padi di desa Pacellekang, Kecamatan Pattalassang, Kabupaten Gowa.

Sampai saat ini belum ada teknologi pengendalian hama yang dapat digunakan. Hasil wawancara dengan petani yang ada di Kabupaten Gowa bahwa kepik hitam resisten terhadap insektisida sintetis, meskipun telah dilakukan penyemprotan secara bertahap, namun kepik hitam masih saja bermunculan dan menyerang malai padi.

Untuk itu, dirasa perlu dilakukan pengendalian hama secara alami dengan menggunakan berbagai jenis tanaman yang dapat dijadikan sebagai insektisida alami untuk mengendalikan serangan kepik hitam pada bulir-bulir tanaman padi.

rumah kaca Fakultas Pertanian serta di Laboratorium Bioteknologi Universitas Hasanuddin Makassar. Penelitian 
ini dilakukan pada bulan Juli sampai bulan Oktober 2012.

Alat yang digunakan pada penelitian ini yaitu kurungankurungan yang berukuran $160 \mathrm{~cm}$ x $65 \mathrm{~cm}$, ember-ember plastik berdiameter $20 \mathrm{~cm}$, botol, kayu, blender, saringan, dan sprayer. Bahan yang digunakan antara lain daun Sirih Merah, biji Srikaya masing - masing sebanyak 100 gram, air cucian beras sebanyak 1 liter dan 5 sendok makan gula pasir.

Tahap-tahap pelaksanaan penelitian diawali dengan melakukan pembuatan MoL, perbanyakan serangga uji, dan uji efektifitas MoL pada kepik hitam. Adapun tahap tersebut sebagai berikut:

\section{Pembuatan MoL Daun Sirih Merah dan Biji Srikaya}

Daun sirih merah dan biji srikaya sebanyak 100 g dicuci bersih dan dihancurkan dengan menggunakan blender lalu dimasukkan ke dalam kaleng cat ukuran $5 \mathrm{~kg}$ yang telah dicuci bersih. Masing-masing ekstrak tersebut di tambahkan air cucian beras sebanyak 1 liter dan 5 sendok makan gula pasir. Bahanbahan tersebut diaduk sampai berwarna coklat kemudian kaleng ditutup rapat di beri isolasi agar tidak ada udara masuk kedalamnya. Campuran ekstrak tersebut di beri label dan kemudian di fermentasi selama 14 hari.

Setelah 14 hari, hasil fermentasi berupa MoL disaring dengan menggunakan saringan kawat kemudian masing-masing MoL di masukkan kedalam botol plastik ukuran 1 liter untuk di gunakan. Namun sebelum digunakan, maka terlebih dahulu dilakukan uji pendahuluan terhadap efektifitas MoL yang akan digunakan.

Perbanyakan Kepik Hitam (Paraeucosmetus pallicornis Dallas)

Dalam pengujian laboratorium dan lapangan digunakan imago kepik hitam yang di kumpulkan dari desa pacellekang kec.pattalassang, Kab. Gowa. Kemudian di lanjutkan dengan pemeliharaan kepik-kepik itu dalam kurungan-kurungan yang berukuran $160 \mathrm{~cm} \times 65 \mathrm{~cm}$ di isi dengan tanaman padi yang sebelumnya sudah ditanam dalam ember-ember plastik berdiameter $20 \mathrm{~cm}$, berisi $4 \mathrm{~kg}$ tanah yang telah di beri air.

\section{Uji Efektifitas MoL Terhadap Kepik Hitam}

Tiga konsentrasi ekstrak masing-masing $3 \%$, 4\%, dan $5 \%$, di aplikasikan ke serangga uji, masing-masing sebanyak 5 ekor imago kepik yang yang sebelumnya telah di kurung di dalam kurungan kasa yang terbuat 
dari kain tile yang di pasang pada kawat berbentuk selinder. Kurungan tersebut di pakai untuk mengurung kepik beserta tanaman padi yang telah ditanam sebelumnya sampai bermalai pada fase masak susu sebagai makanan kepik.

Setiap larutan MoL di aplikasikan dengan menggunakan sprayer melalui lubang pada sisi kurungan sebanyak 100 ml/kurungan. Pengamatan dilakukan pada mortalitas kepik hitam pada tiap konsentrasi. Konsentrasi MoL yang terpilih adalah konsentrasi yang mematikan kepik hitam antara 0 $100 \%$. Hasil uji pendahuluan ini menunjukkan bahwa konsentrasi larutan MoL yang dipilih adalah $3 \%$ yang diencerkan dengan aquades sebanyak $100 \mathrm{~mL}$.

Uji ke efektifan MoL terhadap kepik di lakukan melalui dua metode yaitu:

1. Kontak Integumen

Untuk kontak intugumen, ekstrak dengan konsentrasi yang terpilih di aplikasikan dengan penyemprotan ke seluruh tubuh kepik hitam, dan untuk uji ekstrak melalui makanan di lakukan melalui malai yang di celup kedalam suspensi ekstrak dengan konsentrasi yang sama pada percobaan intugumen kontak. Ada lima perlakuan yang dicobakan yakni; a. kontrol (penyemprotan kepik dengan aquades), b. penyemprotan dengan larutan MoL daun sirih merah, c. penyemprotan dengan larutan MoL biji srikaya. Masing-masing perlakuan di ulang empat kali. Setiap ulangan menggunakan 10 ekor kepik dewasa. Pengamatan dilakukan setengah jam setelah aplikasi MoL dan selanjutnya dilakukan selang waktu 1 jam sampai semua kepik hitam mati. Pengamatan di lakukan terhadap mortalitas kepik hitam dengan rumus mutlak:

$\mathrm{M}=\mathrm{a} / \mathrm{b} \times 100 \%$,

Keterangan:

$\mathrm{M}=$ mortalitas ( $\%)$

$\mathrm{a}=$ banyaknya serangga yang mati

$\mathrm{b}=$ banyaknya serangga yang diujikan.

2. Melalui Makanan

Pada uji larutan MoL melalui makanan, maka kepik di pelihara pada malai yang sudah di celup pada larutan MoL daun sirih merah dan MoL biji srikaya selama 48 jam kemudian serangga yang belum mati di pindahkan ke malai dalam kurungan tanpa dilakukan penyemprotan larutan MoL sampai lima hari.

\section{Analisis Data}

Untuk mengetahui adanya beda nyata antar perlakuan maka datadata yang diperoleh dianalisis 
dengan menggunakan analisis variance (ANAVA) melalui uji $\mathrm{F}$ dengan taraf signifikansi 0,05 . Jika terdapat perbedaan maka dilanjutkan dengan melakukan uji Leat Significance Difference (LSD) yang biasanya juga disebut uji Beda Nyata Terkecil (BNT). Untuk memudahkan peneliti dalam mengolah data, maka dilakukan pengolahan data dengan menggunakan bantuan program SPSS.

\section{HASIL PENELITIAN}

Percobaan MoL daun sirih merah dan biji srikaya dalam mengendalikan kepik hitam yang meyerang malai padi dilihat dari tingkat mortalitas imago kepik hitam yang diujicobakan. Adapun hasil percobaan tersebut sebagai berikut:

Tabel 1. Rata - rata tingkat mortalitas (\%) Kepik Hitam per hari yang diberi perlakuan penyemprotan MoL Daun Sirih Merah dan Biji Srikaya melalui kontak integumen dengan konsentrasi $3 \%$

\begin{tabular}{lcccc}
\hline \multirow{2}{*}{ Perlakuan } & \multicolumn{3}{c}{ Hari } & \multirow{2}{*}{ Rata-rata } \\
\cline { 2 - 4 } & $\mathbf{1}$ & $\mathbf{2}$ & $\mathbf{3}$ & \\
\hline Kontrol & $2,5^{\mathrm{a}}$ & $2,5^{\mathrm{a}}$ & $2,5^{\mathrm{a}}$ & 2.5 \\
Daun Sirih Merah & $60^{\mathrm{c}}$ & $82,5^{\mathrm{c}}$ & $100^{\mathrm{c}}$ & 80.8 \\
Biji Srikaya & $52,5^{\mathrm{bc}}$ & $72.5^{\mathrm{bc}}$ & $95^{\mathrm{bc}}$ & 73.3 \\
\hline \multicolumn{2}{l}{ Keterangan: Pemberian abjad a, b, dan c } & menunjukkan bahwa perlakuan tersebut berbeda \\
\multicolumn{2}{r}{ nyata pada taraf signifikansi } & 0.05 dengan uji BNT.
\end{tabular}




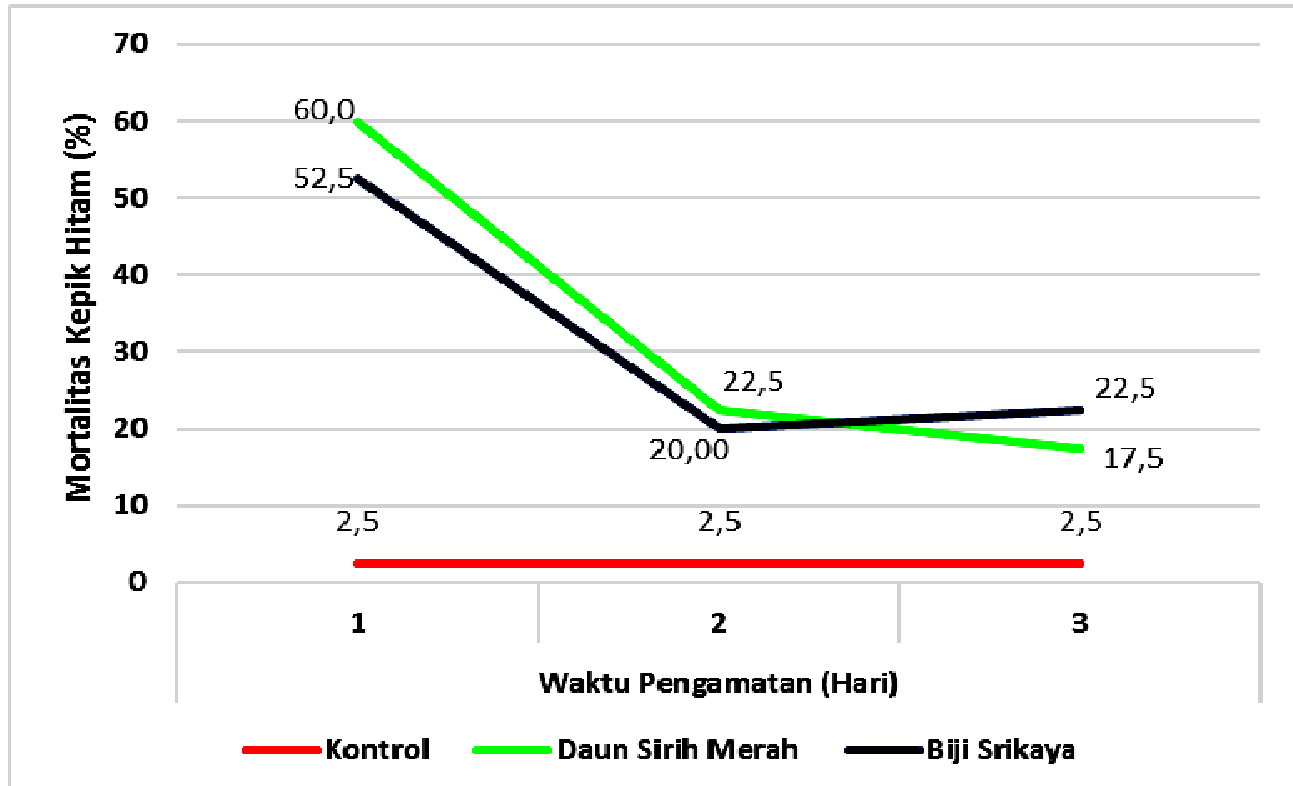

Gambar 1. Persentase mortalitas Kepik Hitam yang diberi perlakuan penyemprotan MoL Daun Sirih Merah dan Biji Srikaya melalui kontak integumen dengan konsentrasi $3 \%$.

Tabel 2. Rata-rata Tingkat Mortalitas (\%) Kepik Hitam per hari pada perlakuan perendaman Malai Padi sebagai makanan Kepik Hitam dengan menggunakan MoL Daun Sirih Merah dan MoL Biji Srikaya konsentrasi 3\% selama 10 detik.

\begin{tabular}{|c|c|c|c|}
\hline \multirow{2}{*}{ PERLAKUAN } & \multicolumn{2}{|c|}{ HARI } & \multirow{2}{*}{ RATA-RATA } \\
\hline & 1 & 2 & \\
\hline Kontrol & $2,5^{\mathrm{a}}$ & $2,5^{\mathrm{a}}$ & 2,5 \\
\hline Daun Sirih Merah & $62,5^{\mathrm{c}}$ & $93^{c}$ & 77,5 \\
\hline Biji Srikaya & $37,5^{\mathrm{b}}$ & $60^{\mathrm{b}}$ & 48,8 \\
\hline
\end{tabular}




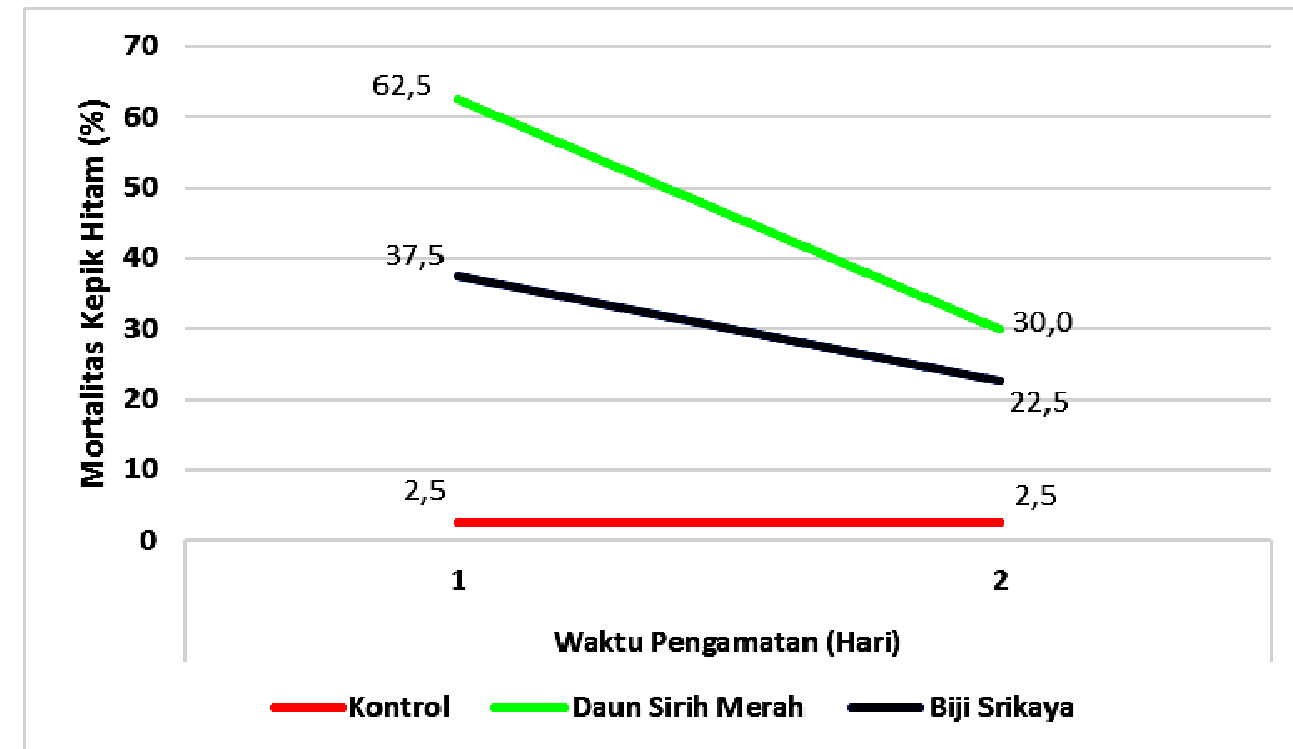

Gambar 2. Persentase mortalitas Kepik Hitam yang diberi perlakuan MoL Daun Sirih Merah dan Biji Srikaya melalui makanan malai padi yang telah direndam larutan MoL dengan konsentrasi 3\%.

Berdasarkan kedua tabel menyerang bulir tanaman padi. tersebut ditemukan bahwa larutan Untuk itu, dilakukan identifikasi MoL daun sirih merah yang mikroba yang terdapat dalam memiliki potensi yang besar dalam larutan $\mathrm{MoL}$ daun sirih merah mengendalikan kepik hitam yang tersebut.

Tabel 3. Hasil identifikasi mikroba yang terdapat pada larutan MoL Daun Sirih Merah

\begin{tabular}{|c|c|c|c|c|c|c|c|}
\hline $\begin{array}{l}\text { Repl } \\
\text { ikasi }\end{array}$ & $\begin{array}{l}\text { Bentuk } \\
\text { Koloni }\end{array}$ & $\begin{array}{c}\text { Warn } \\
\text { a } \\
\text { Kolon } \\
\quad \text { i }\end{array}$ & $\begin{array}{c}\text { Reaks } \\
\text { i } \\
\text { Gram }\end{array}$ & $\begin{array}{c}\text { Endospo } \\
\text { ra }\end{array}$ & $\begin{array}{c}\text { Anaer } \\
\text { ob }\end{array}$ & $\begin{array}{c}\text { Uji } \\
\text { Kolo } \\
\text { ni } \\
\text { Kuni } \\
\text { ng }\end{array}$ & $\begin{array}{c}\text { Hasil } \\
\text { Identifika } \\
\text { si }\end{array}$ \\
\hline 1 & $\begin{array}{l}\text { panjang } \\
\text { / lurus }\end{array}$ & putih & + & + & - & - & Baccillus \\
\hline 2 & $\begin{array}{c}\text { panjang } \\
\text { / lurus }\end{array}$ & putih & + & + & + & + & $\begin{array}{c}\text { Clostridiu } \\
m\end{array}$ \\
\hline 3 & bulat/ & putih & + & - & - & - & Streptomy \\
\hline
\end{tabular}




\begin{tabular}{cc}
\hline Lurus \\
\hline
\end{tabular}

\section{PEMBAHASAN}

Hasil penelitian di atas menunjukkan bahwa penggunaan larutan MoL daun sirih merah yang disemprotkan dengan konsentrasi $3 \%$ dalam aquades sebanyak 100 $\mathrm{mL}$ dapat meningkatkan mortalitas kepik hitam. Data pada tabel 1 menunjukkan bahwa tingkat mortalitas kepik hitam pada setiap hari pada aplikasi larutan MoL dengan konsentrasi $3 \%$ yang dicobakan mulai hari pertama terlihat adanya perbedaan yang nyata. Mortalitas kepik hitam tertinggi terdapat pada perlakuan MoL daun sirih merah yakni $100 \%$ dalam 3 hari nyata sangat berbeda dibanding perlakuan larutan $\mathrm{MoL}$ biji srikaya yang hanya mencapai 95\%. Bahkan pada percobaan tanpa diberikan penyemprotan larutan MoL hanya mencapai 2,5\% dari hari pertama sampai pada hari ketiga pengamatan.

Dari gambar 1 terlihat bahwa persentase mortalitas kepik hitam yang disemprot dengan larutan $\mathrm{MoL}$ daun sirih merah mencapai $100 \%$ meskipun pada hari yang ketiga tren mortalitas kepik hitam mengalami penurunan. Namun demikian, terlihat bahwa kepik hitam mengalami kematian secara menyeluruh pada hari yang ketiga. Hal ini membuktikan bahwa untuk mengendalikan hama yang menyerang bulir-bulit tanaman padi yaitu kepik hitam dapat dilakukan dengan menyemprotkan larutan MoL daun sirih merah konsentrasi $3 \%$ dengan waktu yang dibutuhkan setelah penyemprotan yaitu selama tiga hari untuk mendapatkan mortalitas kepik hitam yang sempurna. Sedangkan pada perlakuan penyemprotan larutan MoL biji srikaya konsentrasi 3\% dengan waktu tunggu selama tiga hari, mortalitas kepik hitam hanya mencapai 95\%. Hal ini tentunya lebih baik dibandingkan dengan tanpa penyemprotan larutan MoL (kontrol) jika mengalami kesulitan dalam mendapatkan daun sirih merah dan hanya tanaman srikaya yang tersedia dan mudah didapatkan.

Percobaan

tersebut menunjukkan bahwa sebenarnya beberapa jenis tumbuhan dapat digunakan sebagai insektisida alami dalam pengenddalian hama yang menyerang tanaman sehingga mengganggu produksi pertanian. Stoll, (1988) mengemukakan bahwa hampir semua jenis tanaman mengandung senyawa alkaloid, terpenoid, fenol, flavonoid, saponin, tanin dan minyak atsiri. Beberapa di antara senyawa tersebut bersifat insektisida yang bekerja sebagai racun kontak, zat penolak (repellent), antifeedant dan penghambat pertumbuhan (Growthinhibitor). Sirih merah yang 
digunakan dalam percobaan ini mengandung flavonoid dan tanni.Kandungan falvonoid dalam daun sirih merah memiliki rasa yyang pahit sehingga dapat menolak jenis larva tertentu (Markham, 1988; Robinson, 1995; Sastrohamidjojo, 1996). Sedangkan biji srikaya (A. squamosa) mengandung senyawa annonain yang terdiri dari squamosin dan asimisin yang bersifat racun kontak terhadap serangga. Dengan demikian biji srikaya dapat digunakan dalam mengendalikan hama (Grainge dan Ahmad, 1988).

Sebagai racun kontak dapat juga terlihat dari penampilan kepik yang akan mati akibat penyemprotan larutan MoLyakni kepik berputar-putar dahulu kemudian merenggangkan tungkainya. Setelah mati tubuh dari kepik berwarna agak kuning kehitaman. Sujanto et. al (1999) melaporkan bahwa ekstrak biji srikaya cukup efektif untuk mengendalikan hama kumbang kedelai Phaedonia inclusa. Senyawa Saponin yang terdapat pada kedua ekstrak tanaman tersebut merupakan senyawa seperti sabun dan dapat menghemolisis sel darah, sehingga apabila diaplikasikan secara kontak ke tubuh serangga akan menyebabkan kerusakan pada integumen. Senyawa flavonoid dapat menghambat transportasi asam amino leusin dan bersifat toksik terhadap serangga. Selain itu, ekstrak daun sirih merah dan biji srikaya mengandung senyawa kimia beracun (senyawa sekunder) juga mengandung bakteri pathogen yakni Bacillus spp, Streptomyces, dan Clostridiumyang terdapat pada ekstrak daun sirih merah.

Hasil percobaan perlakuan perendaman malai padi sebagai makanan kepik hitam, menggunakan 3\% larutan $\mathrm{MoL}$ yang ditunjukkan pada tabel 2 memperlihatkan bahwa persentase mortalitas kepik hitam tertinggi pada hari pertama sampai pada hari kedua yaitu pengaplikasian laruutan MoL daun sirih merah dengan tingkat persentase hari pertama $62,5 \%$ dan hari kedua $30 \%$, sehingga total persentase mortalitas kepik hitam selama dua hari adalah 92,5\%. Sedangkan pada pengaplikasian larutan MoL biji srikaya pada hari pertama sekitar $37,5 \%$ dan hari kedua sekitar $22,5 \%$, sehingga tingkat persentase mortalitas kepik hitam selama dua hari sebanyak $60 \%$.

Setelah kepik hitam yang tidak mati pada masing-masing perlakuan di pelihara selama lima hari dengan pemberian makanan berupa malai padi yang tidak diberi perlakuan, tampak bahwa mortalitas yang di tunjukkan oleh kepik hitam yang merupakan sisa kepik yang masih hidup pada perlakuan perendaman malai padi sebagai makanannya dengan menggunakan 
3\% larutan MoL daun sirih merah menunjukkan tingkat persentase mortalitas yakni $100 \%$ mati pada hari pertama pemeliharaan dengan memberikan makan malai padi yang tidak diberi perlakuan. Sedangkan pada kelanjutan pemeliharaan kepik hitam yang telah 2 hari sebelumnya diberi perlakuan dengan menggunakan larutan MoL biji srikaya menunjukkan tingkat persentase mortalitas kepik hitam sampai hari kelima pemeliharaan tanpa perlakuan pada malai padi sebagai makanannya menunjukkan angka 98\%. Hal ini berarti bawah yang paling efektif dalam pengendalian hama tanaman padi yaitu kepik hitam adalah pengaplikasian larutan $\mathrm{MoL}$ daun sirih merah dengan konsentrasi 3\%.

Berdasarkan pembahasan dua perlakuan tersebut yaitu perlakuan penyemprotan larutan MoL sehingga diharapkan terjadi kontak integumen antara larutan $\mathrm{MoL}$ dengan kepik hitam dan perlakuan perendaman malai padi sebagai makanan kepik hitam dengan harapan bahwa senyawa kimia dan bakteri yang terkandung dalam larutan MoL tersebut dapat menginfeksi kepik hitam melalui sistem pencernaannya. Hasil percobaan membuktikan bahwa perlakuan yang efektif meningkatkan persentase mortalitas kepik hitam adalah melalui kontak makanan. Hal ini didukung oleh Tanada dan kaya (1993) mengungkapkan bahwa pada umumnya bakteri akan menginvasi serangga melalui saluran pencernaannya, sedangkan invasi bakteri terhadap serangga melalui telur, pernafasan, maupun integumen biasanya jarang terjadi. Mekanisme kerja bakteri dalam sistem pencernaan menurut Tanada dan Kaya (1993) bahwa bakteri akan melepaskan enzim lecitinase, proteinase dan kitinase yang akan menghancurkan dinding sel dan masuk ke dalam darah.

Diketahui bahwa larutan MoL mengandung berbagai unsur hara makro dan mikro serta mengandung bakteri yang berpotensi sebagai pendekomposer bahan organik, fertilizer, dan sebagai agen pengendali hama dan penyakit pada tumbuhan (Christine, 2008; Puswasasmita dan Kunia, 2009; BPP Jompo Kulon, 2010; Permana, 2011).

\section{KESIMPULAN}

Hasil penelitian membuktikan bahwa tingkat mortalitas kepik hitam dengan menggunakan $\mathrm{MoL}$ daun sirih merah melalui kontak integumen selama 2 hari yaitu sebesar $82,5 \%$, penggunaan $\mathrm{MoL}$ biji srikaya sebesar $72,5 \%$, dan tanpa campuran MoL sebesar 2,5\%. Sedangkan perlakuan melalui kontak makanan kepik hitam melalui perendaman malai padi menunjukkan bahwa perendaman malai padi sebagai makanan kepik 
hitam selama 2 hari dengan MoL daun sirih merah yaitu sebesar $92,5 \%$, perendaman malai padi dengan MoL biji srikaya sebesar $60 \%$, dan perendaman malai padi tanpa campuran MoL daun sirih merah dan biji srikaya sebesar $2,5 \%$. Dengan demikian daya bunuh MoL daun sirih merah melalui kontak makanan dengan cara perendaman malai padi lebih tinggi dibandingkan dengan perlakukan MoL daun sirih merah melalui kontak integumen dengan cara penyemprotan.

\section{SARAN}

Sebaiknya dilakukan penelitian lebih lanjut untuk mengidentifikasi metabolit sekunder mikroba yang terdapat dalam larutan MoL daun Sirih merah dan larutan MoL ekstrak biji Srikaya yang berperan untuk mematikan kepik hitam.

\section{DAFTAR PUSTAKA}

Baskoro.2009. Buletin peramalan OPT Vol 7 No 1. Edisi XI. Direktorat Jenderal Tanaman Pangan Balai Besar Peramalan OPT.

BPP Jompo Kulon. 2010. Mikro Organisme Lokal. Kamis,05 Agustus 2010.

Christine.2008. Cara membuat MOL Tapai. Sumber Sobirin,http:// clearwaste.blogspot.com/.Sabtu , 01 Maret 2008.
Grainge,M. and Ahmed, S. 1988. Hand Book of Plant with Pest Control Properties. John Willey \& Sons. New York 470 pp.

Markhan, K.R. 1988. Cara Mengedintifikasi Flavonoid. ITB. Bandung.

Permana, Dedi. 2011.Kualitas

Pupuk Organik Cair Dari Kotoran Sapi Pedaging yang di Fermentasi Menggunakan Mikroorganisme Lokal. Departemen Ilmu Produksi dan Teknologi Peternakan Fakultas Pertanian IPB Bogor. Skripsi. 40 halaman.

Purwassasmita M., Kunia K.2009. Mikroorganisme Lokal Sebagai Pemicu Siklus Kehidupan Dalam Bioreaktor

Tanaman.Seminar Nasional Teknik Kimia Indonesia ( SNTKI, 2009) Bandung 19-20 Oktober 2008.

Rauf, Aunu dan Lanya, Harsono. 2008. Laporan Hasil Pengamatan Lapangan Klarifikasi Hama Baru Kepik Penghisap Bulir Padi di Provinsi Sulawesi Utara. Tanggal 4-5 Desember.

Robinson J.C. 1995. Atom Optics. A New Testing Ground for Quatum Choos. The University of Texas Austin.

Sastrohamidjojo, Hardoyo. 1996. Sintesis Bahan Alami.Universitas Gajah Mada Yogyakarta. 
Tanada,Y.,Kaya, H.K. 1993. Insect Pathology. Academic Press. Inc. New York .666pp.

Tim Kajian BBPOT dan IP3OPT Pinrang. 2011. Laporan Hasil
Kerja Dinamika Popuulasi Pengendlian Kepik Hitam, Sulawesi Selatan. 